Огляди літератури, оригінальні дослідження, погляд на проблему

УДК 617.58-003.4-085.825

DOI 10.11603/1811-2471.2017.v0.i2.7724

\title{
ЛІКУВАЛЬНА ФІЗКУЛЬТУРА ПРИ ТЕРАПІЇ ІШЕМІЧНОЇ ХВОРОБИ КІНЦІВОК
}

\section{сл. В. Андріюк}

Львівський начіональний медичний університет імені Данила Галицького

РЕзЮМЕ. Мета - дослідити роль фізичної терапії у запобіганні прогресування ішемічної хвороби нижніх кінцівок.

Матеріал і методи. У роботі висвітлено досвід використання рухової терапії у пацієнтів з ішемічною хворобою нижніх кінцівок у другій стадії захворювання. Навантаження вибирали за допомогою стрес-тесту, який визначали відповідно до локалізації закупорки в артеріях. Визначення відстані початкового безболісного інтервалу ходьби проводили з використанням бігової доріжки або крокоміра, під наглядом лікаря вимірювали відстань в метрах до першого відчуття болю в кінцівках. Повторні випробування ходьби проводили через місяць, а потім через 3 і 6 місяців. Дослідження показали зростання безболісного інтервалу ходьби з 25 \% до 120 \%. Розвиток оптимального колатерального кровообігу тривав більше 3-10 місяців.

Результати. Інтенсивні інтервальні тренування складалися з вправ, що виконуються під час стрес-тесту в залежності від висоти судинних уражень. Після серії вправ проводили 2-3-хвилинні перерви. Комплекс 3 4-9 вправ повторювали 2-3 рази на день і через кожні 1-2 місяці проводили нові випробування максимальної кількості вправ в одній серії. Як одну з форм терапії рухом використовували нордичну ходу, при якій працюють усі 600 м'язів тіла, перевантаження несучих суглобів зменшується на 30 \%. Кровотік на пальцях збільшувався з 35 мм справа і 42 мм зліва до 88 мм справа і 93 мм зліва після 2 років. Пальцево-плечовий індекс зріс від 0,35 справа і 0,39 зліва до 1,19 справа і 1,25 зліва. Індекс кульгавості збільшився на 300-400 м, що вказує на ефективність і важливість терапевтичної ходи в лікуванні облітеруючих захворювань кінцівок.

КЛючОВІ СлОВА: периферійний облітеруючий ендартеріїт кінцівок; інтервальні тренування; кінетотерапія; інтервал кульгавості; нордична хода.

Вступ. Для ішемічної хвороби кінцівок характерним $€$ недостатнє кровопостачання, що призводить до ішемії і наступного пошкодження або некрозу тканини, кров до якої постачає певна уражена артерія. Ішемічний синдром викликаний або недопостачанням окисненої крові, або недостатнім вимиванням метаболічних відходів. Компенсація ішемії буває як метаболічна, так і судинна. Відбувається підвищена екстракція кисню 3 крові, а при активних вправах, тренінгу проходить певна анатомічна перебудова м'язових волокон та зміна енерговиділення з анаеробного на аеробне. Будівництво колатерального кровообігу $\epsilon$ активною дією, а не лише звичайним розширенням вже існуючих судин. Йдеться про гіпертрофію стінки зі збільшенням числа клітин. Чим вище розташована закупорка артерії, тим кращою $\epsilon$ можливість бічного кровообігу. При робочому навантаженні відбувається виразне зниження периферійного судинного опору, особливо у м'язах, які переважно забезпечуються кров'ю за рахунок кровопостачання шкіри. Відносна ішемія під час роботи формує на основі накопичених судинорозширювальних метаболітів повторні судинорозширювальні імпульси для утворення бічногоколатерального кровообігу.

Приблизно у 90 \% випадків причиною хронічної ішемічної хвороби кінцівок $\epsilon$ атеросклероз. Найчастіше від нього страждають нижні кінцівки. При ішемічній хворобі верхніх кінцівок з точки зору етіології перше місце займають васкуліти. На основі атеросклеротичного процесу відбувається поступове звуження, аж до перекриття, просвіту судин. В ургентних випадках доходить до закупорювання артерії тромботичним процесом на основі вже існуючих стенотично-оклюзійних змін у кровоносних судинах або при емболії, коли відбувається закупорювання судини кров'яним субстратом - емболом, занесеним з певного джерела в організмі (наприклад, з серця при інфаркті міокарда, при фібриляції передсердь, з серцевої аневризми або при вадах клапанів).

Клінічні ознаки периферійної облітеруючої хвороби кінцівок - ЗПА - спостерігаємо на ІІ стадії захворювання, коли виникає біль при фізичному навантаженні. У випадку ураження нижніх кінцівок - це біль при ходьбі, на так звану відстань кульгавості. Пацієнт після прогулянки на певну відстань мусить зупинитися через біль, який найчастіше виникає в ділянці литок, або, залежно від місця звуження чи закупорювання судини цей біль може з'явитися в іншому місці нижньої кінцівки. Відповідно до відстані, при якій виникає біль, ішемію кінцівки поділяють на наступні стадії: Іla стадія - пацієнт без болю минає відстань більш ніж 200 метрів; ІІб стадія - у пацієнта виникає біль в ногах на відстані менш ніж 200 метрів; IIc стадія - відстань кульгавості $\epsilon$ дуже коротка менше 50 метрів. III стадія ішемічної хвороби кінцівок - біль у спокої або при ходьбі на відстань менш ніж 25 метрів, а IV стадія характеризується виразково-некротичними змінами тканин. Ліку- 
Огляди літератури, оригінальні дослідження, погляд на проблему

вання ішемічної хвороби кінцівок має бути комплексним і, крім медикаментозної терапії, хірургічного чи ендоваскулярного лікування, включати фізичне лікування, особливо лікування рухом.

Матеріал і методи дослідження. Перш ніж застосувати хірургічне або ендоваскулярне реваскуляризаційне лікування, при відсутності ознак критичної ішемії кінцівок, потрібно, крім медикаментозної терапії, робити акцент на фізичному лікуванні, яке часто недооцінюють. Фізична терапія важлива при всіх стадіях ішемічної хвороби кінцівок але, головним чином, при II стадії захворювання. Суттєве значення має лікування рухом - кінезотерапія. Ії̈ роль полягає у формуванні ефективної колатеральної системи, збільшенні потужності колатерального кровообігу, покращенні техніки ходьби, підвищенні больового порогу і метаболічної адаптації ішемізованих частин. У здорової людини під час інтенсивного руху кровопостачання м'язів збільшується аж у 20 разів. При артеріальних облітераціях м'язова активність призводить до збільшення швидкості потоку в колатералях та до росту колатералей. Якщо м'язова активність слабка, утворюється набагато менший колатеральний кровообіг. Рухова терапія полягає у систематичному навантаженні м'язових груп, які розташовані у дистальній частині відносно закупорення судини. Вправи виконують кілька разів на день так, щоб не з'явився біль. Найкращим є фазове навантаження і вправи, вибрані відповідно до локалізації закупорення судини. Суть вправ при захворюваннях периферійних судин полягає в індивідуальній підготовці вправ відповідно до розвитку захворювання та індивідуальних можливостей пацієнта.

Одиницю тренування вибирають за допомогою стрес-тесту, який визначається відповідно до локалізації закупорення в артеріальному руслі кінцівок. При аорто-клубових ураженнях пацієнт під час стрес-тесту виконує присідання і напівприсідання, а при стегново-підколінних закупореннях та перекриттях верхньої третини артерій гомілки - вставання навшпиньки. При локалізації закриття у дистальній 2/3 частині гомілки та в ділянці ноги пацієнт у горизонтальному положенні з піднесеними нижніми кінцівками виконує згинання ноги у щиколотці вперед і назад - підошвове та дорсальне згинання у гомілковостопному суглобі, або обертання щиколотки. Правильне тестування відстані початкового безболісного інтервалу ходьби - інтервалу кульгавості - проводять з використанням бігової доріжки або крокоміра - під наглядом лікаря або фізіотерапевта вимірюється відстань у метрах, яку пацієнт пройде до появи першого відчуття болю у кінцівках. При тестуванні ходьби темп має складати 120 кроків за хвилину.
При ураженнях верхніх кінцівок за наявності стенозу або закупорення підключичної, пахвової або плечової артерій під час стрес-тесту і виконання вправ використовують гантелі вагою 1-2 кг. 3 опущеними донизу руками пацієнт має виконувати згинання в ліктьовому суглобі у напрямку до грудей і підносити руки доверху ширше плечей та опускати вниз по швах. Число вправ одиниці тренінгу складає 2/3 від загальної кількості вправ, які пацієнт виконав аж до появи ішемічного болю такої інтенсивності, при якій був змушений вправи припинити, причому темп вправ - близько 40 за хвилину.

Власний інтенсивний інтервальний тренінг складається з вправ, які виконуються під час стрес-тесту відповідно до висоти ураження судини. Після серії вправ потрібно зробити паузу на 2-3 хвилини. Комплекс вправ з 3-10 серій треба повторювати щонайменше 2-3 рази на день та кожні 4-6 тижнів проводити нове тестування максимальної кількості вправ в одній серії. У випадку покращання здатності знову потрібно встановити 2/3 кількості вправ, які пацієнт має виконувати так само, як і раніше.

Повторне тестування ходьби повинно бути проведено через 6 тижнів, за винятком відстані кульгавості, що складає менше 50 м, та стадії IVa, коли контроль необхідно провести через 1 тиждень. Далі проводиться контроль через 3 і 6 місяців і потім, як правило, кожні шість місяців.

Окремі вправи. У положенні лежачи на спині з піднесеними вгору кінцівками потрібно виконувати підошовне і дорсальне згинання пальців стопи, згинання ноги у щиколотці вперед і назад-підошовне і дорсальне згинання щиколотки, обертання ноги у щиколотці, притягання коліна до живота і випрямлення його не торкаючись мата. Сидячи підняти стопу навшпиньки, почергово, опираючись на п'яту, рухати пальцями ніг. Стоячи піднятись навшпиньки, зробити напівприсідання, почергово ставити на сходинку праву і ліву ноги.

Вправи у воді, як і вправи проти підвищеного опору, не тільки збільшують складність вправ, але й підвищують їх ефективність. При виконанні вправ у воді відбувається покращення тонізації судинної системи, зменшення дії сили тяжіння, від вправ з підвищеним опором активізується м'язова робота.

Природна ходьба $\epsilon$ дуже корисним тренувальним заходом для розвитку колатерального кровообігу під впливом постійної м'язової роботи. Швидкість під час тренування може складати 120 кроків за хвилину при інтенсивному тренуванні, або 60 кроків за хвилину при повільному. Рекомендується починати з півгодинної прогулянки і поступово продовжувати складність ходь- 
Огляди літератури, оригінальні дослідження, погляд на проблему

би у такій послідовності: 1 доба - ходьба, 2 доба - темп ходьби, 3 доба - складніша місцевість. Тренування ходьбою треба проводити щонайменше 5 днів на тиждень, доповнюючи ії вправами для гіпотрофічних м'язових груп.

Пацієнта необхідно правильно мотивувати, тоді тренування м'язів буде результативним. Цілком очевидно, що тренуватися треба регулярно впродовж тривалого періоду. Зворотний зв'язок $\epsilon$ дуже важливим, бо якщо пацієнт бачить покращання, він утверджується у своєму позитивному ставленні до реабілітації у формі терапії рухом. Проведені дослідження показали зростання безболісної відстані при тренуванні ходьбою від $30 \%$ до $150 \%$. На розвиток оптимального колатерального русла можна розраховувати за 3-12 місяців.

До протипоказань для інтенсивного інтервального тренінгу належать загальний тяжкий стан пацієнта, серйозні неврологічні та ортопедичні захворювання, тяжка серцева недостатність, часті напади стенокардії, неконтрольована - нестабільна гіпертензія, III і IV стадії облітеруючого захворювання артерій кінцівок, за винятком стадії IVa.

У якості однієї з форм кінезотерапії ми рекомендуємо так звану нордичну ходу. Від звичайної ходьби вона відрізняється тим, що пішохід використовує спеціальні телескопічні палиці, тим самим знижуючи напругу в шийному відділі хребта. Нордична хода активізує трицепс, великий грудний м'яз, м'язи задньої частини плечового пояса, широкі м'язи спини. При цій ходьбі працюють майже усі 600 м'язів тіла, а у порівнянні з бігом тут значно менше навантаження на коліна і кульшові суглоби. Перевантаження несучих суглобів $\epsilon$ на 30 \% менше, тому нордична хода корисна при дегенеративних захворюваннях хребта, а також для пацієнтів з остеопорозом. Нордична хода - це динамічна кондиційна ходьба у різних за складністю природних рельєфів місцевостях. На додаток до вищезазначених переваг слід вказати на ії доступність для всіх, участь у роботі верхніх і нижніх кінцівок, ефективне спалювання жирів та зниження ваги тіла, підвищення імунітету, збільшення продуктивності діяльності, зняття стресу, тренування великого і малого кола кровообігу, уповільнення процесів старіння, а також перебування на природі.

\section{Клінічні випадки}

Ефективність і важливе місце кінезотерапії при лікуванні облітеруючих захворювань кінцівок можемо підтвердити на прикладі декількох коротких історій хвороб пацієнтів, які лікувалися в нашій клініці ангіології.

1. Пацієнт О. В., 1957 року народження, спостерігається проксимальний тип перекриття в ді- лянці інфраренальної аорти та клубових артерій 3 колатеральним кровотоком від дистальної частини поверхневої стегнової артерії. На додаток до лікування вазодилататорами і антиагрегантами протягом багатьох років регулярно займається ходьбою - щоденно проходить 5-8 км місцевістю з рельєфом середньої складності. у 2014 р. кровотік на пальцях справа 38 мм рт. ст., зліва 44 мм рт. ст., індекси ТВІ (пальце-плечовий індекс) справа 0,32 ТВI, зліва - 0,37. Ми проводили регулярний моніторинг пацієнта кожні 6 місяців. Під час останньої перевірки у 2017 році виявлено підвищення індексів ТВI на 0,64 справа і на 0,65 зліва. Про кульгавість відомостей на цей раз не подає, без болю пройде більше кілометрів. На момент обстеження операція показана не була.

2. Пацієнт К. П., 1954 року народження, хворий на діабет, використовує пероральні протидіабетичні засоби, курець, перший раз обстежений у нашій клініці 01/2013 - на УЗД підтверджено тип ураження - дистальне закупорення, потім була проведена цифрова субтракційна ангіографія (DSA), де було підтверджено закупорення у нижніх гілках підколінної артерії зліва з відсутністю кровотоку в ділянці периферійних судин лівої нижньої кінцівки, за винятком малогомілкової артерії, де спостерігається ослаблений переривчастий кровотік. Периферійні зміни також присутні в артеріальній системі правої нижньої кінцівки. Зліва ознаки критичної ішемії кінцівок $з$ болем спокою кінцівки на початку та майже нульовим тиском крові на пальці лівої нижньої кінцівки. Справа індекс 0,93. Кульгавість до 10-20 м ходьби. Пацієнту було рекомендоване консервативне лікування з огляду на технічну неможливість виконання хірургічного чи інтервенційного втручання. Йому була призначена вазодилатаційна терапія, антиагреганти - ACA, а на початку лікування також низькомолекулярний гепарин. Одночасно пацієнтові було роз'яснено необхідність цілковитої заборони куріння і рекомендовано фізіотерапію рухом. Пацієнт перестав курити, продовжує тренування ходьбою, їздить на мотоциклі, виконує ізометричні вправи з поступовим збільшенням навантаження. Вже за 3 місяці клінічний стан пацієнта покращився, пальцевий тиск на лівій нижній кінцівці складав 57 мм рт. ст., а індекс ТВI - 0,48. Без болю проходить більше ніж 500 м. Під час останньої перевірки в 2017 р. пальцеві індекси: справа ТВІ 1, 19, зліва $-0,95$, ходить без обмежень, не курить. На УзД спостерігається значне покращання параметрів кровотоку як зліва, так і справа. Клінічна стадія хвороби пацієнта змінилася з III на Ila-I.

3. Пацієнт Н. О., 1953 року народження, курець, хворий на гіпертонічну хворобу. У 2014 році 
Огляди літератури, оригінальні дослідження, погляд на проблему

підтверджено проксимальний тип перекриття облітеруючого ураження артеріальної системи нижньої кінцівки. Наявне двостороннє закупорення зовнішньої клубової артерії, в поверхневій стегновій артерії постстенотичні низького опору колатеральні потоки. Клаудикація на початку вже після 30 м ходьби, особливо зліва в ділянці стегнової кістки та по цілій лівій нижній кінцівці. Пальцеві індекси кровотоку на початку справа ТВІ 0,68, TBI зліва 0,42 (пальцевий тиск зліва 60 мм рт. Ст). Пацієнтові була призначена вазодилатаційна і антиагрегантна терапія з абсолютною забороною куріння та рекомендовано поступове тренування ходьбою. На початку спостерігали лише незначне покращання інтервалу кульгавості на 50-70 м ходьби. Куріння обмежив. Йому було рекомендоване консервативне лікування, більш інтенсивний тренінг за допомогою ходьби. Пацієнт перестав курити та, крім інтервального тренінгу ходьбою, включив до нього також присідання i напівприсідання. Відбулося поступове зростання інтервалу кульгавості на 150-200 м. Після останнього огляду в 2017 році виявлено зростання ТВІ зліва на 0,62 (пальцевий тиск 87 мм рт. ст.). Інтервал кульгавості зріс на 400 м. У пацієнта відбулося клінічне поліпшення зі стадії ІІс на стадію Ila.

Висновки. У лікуванні ішемічної хвороби кінцівок кінезотерапія займає важливе місце. Інтервальний м'язовий тренінг та тренування ходьбою $\epsilon$ важливим засобом розвитку колатерального русла на перших стадіях облітеруючого захворювання артерій, має значення також після ендоваскулярних та хірургічних реваскуляризаційних втручань для профілактики рецидиву ішемії та прогресування ішемічної хвороби кінцівок. Для підвищення якості фізичного консервативного лікування облітеруючих захворювань артерій кінцівок дуже важливим $\epsilon$ міждисциплінарний підхід, зокрема співпраця ангіолога, судинного хірурга та фізіотерапевта з точним визначенням терапевтичних алгоритмів та адекватним навчанням пацієнта.

\section{ЛІТЕРАТУРА}

1. Andriyuk L. V. Vertebral and Extravertebral joints diseases: Manual diagnosis and correction / L. V. Andriyuk. - Lviv, 2012. - 236 p.

2. Dubrovskyi V. I. Biomechanics / V. I. Dubrovskyi. 2008. -669 p.

3. Epyfanov V. A. Spine osteochondrosis. Diagnosis, treatment, prevention / V. A. Epyfanov, A.V. Epyfanov. MED press-inform, 2008. - 272 p.

4. Fedoriv, Y.-R. M. General physiotherapy, teach. Guidance / Y.-R. M. Fedoriv, A. L. Filipyuk, R.Y. Hrytsko. Kyiv: Health, 2004. - 222 p.

5. Figurova M. Kinezioterapia pri liečbe ischemickej

choroby končatín / M. Figurova // Eniologia Cloveca. 2016. - Vol. 11. - P. 5-8.

6. Mukhin V. N. Physiotherapy. Physical rehabilitation: a textbook. 3-rd ed., Revised. and fulfilled / V. N. Mukhin. - 2009. - P. 70-95.

7. Vladimirov O.A. Physiotherapy: textbook / V. V. Ezhov, G. M. Ponomarenko (Ed.). - National Medical Academy of Postgraduate Education named after P. L. Shupyk. - 2013. - 428 p.

8. PopovH. I. Biomechanics/H. I. Popov.-2005.-Vol. 256.

9. Zahrevskiy V. I. Biomechanics of exercises / V. I. Zahrevskiy // MSU. - 2003. - Vol. 136.

\section{REFERENCES}

1. Andriyuk, L.V. (2012). Vertebral and Extravertebral joints diseases: Manual diagnosis and correction. Lviv.

2. Dubrovskyi, V.I. (2008). Biomechanics, 669.

3. Epyfanov, V.A., Epyfanov, A.V., (2008). Spine osteochondrosis. Diagnosis, treatment, prevention. MED press-inform, 272.

4. Fedoriv, Y.-R.M., Filipyuk, A.L., Hrytsko R.Y., (2004). General physiotherapy, teach. guidance. Kyiv: Health.

5. Figurova, M (2016). Kinezioterapia pri liečbe ischemickej choroby končatín. Eniologia cloveca, 11, 5-8.

6. Mukhin, V.N. (2009). Physiotherapy. Physical rehabilitation: a textbook. 3-rd ed., Revised. and fulfilled, 70-95.

7. Vladimirov, O.A., Ezhov, V.V., Ponomarenko, G.M. (Ed.). (2013). Physiotherapy: textbook National Medical Academy of Postgraduate Education named after P.L. Shupyk, 1, 428.

8. Popov, H.I. (2005). Biomechanics, 256.

9. Zahrevskiy, V.I. (2003) Biomechanics of exercises. MSU, 136. 


\title{
Огляди літератури, оригінальні дослідження, погляд на проблему ЛЕЧЕБНАЯ ФИЗКУЛЬТУРА ПРИ ТЕРАПИИ ИШЕМИЧЕСКОЙ БОЛЕЗНИ КОНЕЧНОСТЕЙ
}

๑л. В. Андриюк

\author{
Львовский национальный медицинский университет имени Данила Галицкого
}

РЕЗЮМЕ. Цель - исследовать роль физической терапии в предотвращении прогрессирования ишемической болезни нижних конечностей.

Материал и методы. В работе освещен опыт использования двигательной терапии у пациентов с ишемической болезнью нижних конечностей во второй стадии заболевания. Нагрузку выбирали с помощью стресс-теста, который определяли в соответствии с локализацией закупорки в артериях. Определение расстояния начального безболезненного интервала ходьбы проводили с использованием беговой дорожки или шагомера, под наблюдением врача измеряли расстояние в метрах до первого ощущения боли в конечностях. Повторные испытания ходьбы проводили через месяц, а затем через 3 и 6 месяцев. Исследования показали рост безболезненного интервала ходьбы с 25 \% до 120 \%. Развитие оптимального коллатерального кровообращения длилось более 3-10 месяцев.

Результаты. Интенсивные интервальные тренировки состояли из упражнений, выполняемых во время стресс-теста в зависимости от высоты сосудистых поражений. После серии упражнений проводили 2-3-минутные перерывы. Комплекс по 4-9 упражнений повторяли 2-3 раза в день и через каждые 1-2 месяца проводили новые испытания максимального количества упражнений в одной серии. В качестве одной из форм терапии движением использовали нордическую ходьбу, при которой работают все 600 мышц тела, перегрузки несущих суставов уменьшаются на 30 \%. Кровоток по пальцам увеличивался с 35 мм справа и 42 мм слева до 88 мм справа и 93 мм слева после 2 лет. Пальцево-плечевой индекс вырос с 0,35 справа и 0,39 слева до 1,19 справа и 1,25 слева. Индекс хромоты увеличился на 300-400 м, что указывает на эффективность и важность терапевтической ходьбы в лечении облитерирующих заболеваний конечностей.

КЛЮчЕВЫЕ СЛОВА: периферический облитерирующий эндартериит конечностей; интервальные тренировки; кинезотерапия; интервал хромоты; нордическая ходьба.

\section{EXERCISE THERAPY IN THE TREATMENT OF ISCHEMIC LIMBS DISEASE}

\section{Danylo Halytskyi Lviv National Medical University}

\section{@L. V. Andriyuk}

SUMMARY. The aim - to investigate the influence of physical therapy for preventing the progression of ischemia and ischemic limbs.

Materials and Methods. We used motor therapy in patients with ischemic disease of the lower limbs in the second stage of the disease. The training unit selected using the stress test, which is determined according to the localization of blockage in the arterial. Proper testing distances of initial painless interval of walk was performed using a treadmill or a pedometer, when under medical supervision measured distance in meters until the first sensation of pain in the limbs. Repeated tests of walking were performed after a month, except lameness distances that is less than 50 meters, then at 3 and 6 months. Studies have shown growth during the painless distances of disease from $25 \%$ to $120 \%$. The development of optimal collateral circulation was over 3-10 months.

Results. Own intense interval training consisted of exercises performed during the stress test according to the height of vascular lesions. After a series of exercises 2-3 minutes break. A set of exercises with 4-9 series was repeated 2-3 times a day and every 1-2 months was performed new tests of the maximum number of exercises in one series. As a form of movement therapy we used Nordic walking. In this walking all 600 muscles of the body were working, overloading bearing joints was by $30 \%$ less. Blood flow on the toes from $35 \mathrm{~mm}$ right and $42 \mathrm{~mm}$ left increased to $88 \mathrm{~mm}$ right and $93 \mathrm{~mm}$ left after 2 years. Finger-brachial index from 0.35 of the right and 0.39 left increased to 1.19 right and 1.25 left. Index lameness by 300-400 meters was increased, suggesting the effectiveness and importance of therapeutic walking in the treatment of limbs obliterating diseases.

KEY WORDS: peripheral occlusive disease of the limbs; interval training; kinesitherapy; interval lameness; Nordic walking. 